\title{
A Novel Method for Determining Peroxidase Activities Using p-Acetamidophenol Analogs
}

\author{
Masanobu Shiga*, Kenshi Yakata*, Masaaki Aoyama**, Kazumi Sasamoto*, \\ Makoto TAKAGI*** and Keiyu UENo* \\ *Dojïndo Laboratories, Tabaru, Mashiki-machi, Kumamoto 861-22, Japan \\ **Yamagata Research Institute of Technology, Aza-Kurumanomae, Numagi, Yamagata 990, Japan \\ *** Department of Applied Chemistry, Faculty of Engineering, Kyushu University, \\ Hakozaki, Fukuoka 812, Japan
}

\begin{abstract}
p-Acetamidophenol analogs were proved to produce highly fluorescent compounds upon oxidation with peroxidase and hydrogen peroxide. The chemical structure of the major fluorescent product derived from $p$-acetamidophenol was determined to be 5,5'-diacetamido-2,2'-bisphenol. A survey of 25 acetamidophenol analogs showed that $p$ alkylamidophenols were suitable substrates for determining the peroxidase activity. In a region of low peroxidase activity in particular, the fluorescent intensity from $p$-acetamidophenol is more than twenty-times higher than that of 3(4-hydroxyphenyl)propionic acid (HPPA), which is widely used as a fluorogenic reagent for determining peroxidase activity. The detection limit of peroxidase activity was $0.5 \mu \mathrm{U} / \mathrm{ml}$ at a signal-to-noise $(S / N)$ ratio of 3 .
\end{abstract}

Keywords $p$-Acetamidophenol, peroxidase activity, fluorometric assay

An enzymatic analysis of various organic and inorganic substances is the most popular method because of its specificity and sensitivity. Especially peroxidase is a widely used enzyme in biochemical assays and clinical analyses. In biological assays, peroxidase-labeled proteins, such as monoclonal antibody, avidin and streptoavidin, are used for enzyme immunoassays (EIA). In clinical analyses, the amounts of components in blood or urine samples can be determined by measuring the amount of hydrogen peroxide either colorimetrically or fluorometrically, which is produced by a reaction with the corresponding oxidase. A number of reagents or techniques for colorimetric analyses have been described in the literature..$^{1-3}$ For instance, Guilbault et al. found that homovanillic acid, $p$-hydroxyphenylacetic acid, tyrosine and tyramine are good substrates for peroxidase, giving fluorescent compounds, by examining several $p$-substituted phenolic compounds.4,5 Among these compounds, Ohkura et al. proved that 3-(4hydroxyphenyl)propionic acid (HPPA) is the most useful and sensitive reagent for measuring peroxidase activity. $^{6}$ By using HPPA as a substrate for horseradish peroxidase (HRP), the human growth hormone (hGH) was analyzed ${ }^{7}$ and the human chorionic gonadotropin (hCG) was monitored by high-performance liquid chromatography (HPLC) analysis. ${ }^{8}$

In general, the detection sensitivity of a fluorometric assay is affected by the fluorescence background from the components of solutions, such as buffers, solvents and especially HRP substrates, that give fluorescent products by an oxidation reaction. For a highly sensitive and accurate measurement of HRP activities, a low fluorescence background of the substrate is required. However, the purification of HPPA is not easy because of its troublesome procedure, such as distillation or isolation by gel-column chromatography.

In the present study we found that $p$-acetamidophenol analogs were good reagents for a highly sensitive measurement of the HRP activities, and also determined the chemical structure of a fluorescent product derived from $p$-acetamidophenol in the enzymatic reaction. Twenty $p$-acetamidophenol analogs (compound 2-20, 25, Table 1) were synthesized, of which 25 compounds were examined as an HRP substrate. Among $p$ acetamidophenol analogs, highly sensitive and stable derivatives are selected for the HRP assay.

\section{Experimental}

\section{Apparatus}

Thin-layer chromatography (TLC) was performed on Merck Kieselgel $60 \mathrm{~F}_{254}$ plates. ${ }^{3} \mathrm{H}$-nuclear magnetic resonance (NMR) spectra were measured on a Bruker AC 200 spectrometer, operating at $200 \mathrm{MHz}$ with tetramethylsilane used as an internal standard. The splitting patterns were designated as: $s$, singlet; $d$, doublet; $t$, triplet; $q$, quartet; $q t$, quintet. HPLC analyses were carried out with a Shimadzu LC-6A liquid chromatography equipped with a UV detector operating 
at a wavelength of $254 \mathrm{~nm}$ and a fluorescence detector at $328 \mathrm{~nm}$ and $430 \mathrm{~nm}$ as the excitation $\left(\lambda_{\max }\right)$ and the emission $\left(\lambda_{\max }\right)$ wavelength, respectively. The column was a TSKgel ODS120T (150 mm $\times 4.6 \mathrm{~mm}$ i.d.; particle size: $5 \mu \mathrm{m}$ ) obtained from TOSOH; the column temperature was $40^{\circ} \mathrm{C}$. The mobile phase was $50(\mathrm{v} / \mathrm{v}) \%$ aqueous acetonitrile, unless otherwise noted, which was pumped at a flow rate of $1.0 \mathrm{ml} / \mathrm{min}$. The fast-atom bombardment mass spectra (FAM-MS) were measured on a JEOL AX-505W mass spectrometer. Fluorescence spectra were taken on a Hitachi 650-60 fluorescence spectrophotometer using a $1 \mathrm{~cm} \times 1 \mathrm{~cm}$ quartz cell; the temperature of the cell holder was controlled with circulated water.

\section{Materials}

Horse-radish peroxidase (HRP, $158 \mathrm{U} / \mathrm{mg}$ ) was purchased from Wako Pure Chemicals (Osaka, Japan). The stock solution of HRP was prepared as a $50 \mathrm{mM}$ phosphate buffered saline (PBS) solution (pH 7.0) containing $0.2(\mathrm{w} / \mathrm{v}) \%$ bovine serum albumin (BSA) at the concentration of $1 \mathrm{U} / \mathrm{ml}$; it was stored in a refrigerator and diluted with the PBS buffer. 2-[4-(2Hydroxyethyl)-1-piperazinyl]ethanesulfonic acid (HEPES), 2-morpholinoethanesulfonic acid (MES) or Tris buffer ( $50 \mathrm{mM}$ each) were used for the enzymatic studies. The HRP activities were re-estimated by the guaiacol method. ${ }^{9}$ A stock solution of hydrogen peroxide was prepared at $200 \mathrm{mM}$ with PBS. Stock solutions of compounds $1-26$ were prepared at $10 \mathrm{mM}$ in $50 \mathrm{mM}$ PBS (pH 7.5). Compounds 19 and 23 were dissolved in dimethylsulfoxide (DMSO).

\section{Syntheses of the substrates}

$p$-Acetamidophenol analogs were synthesized from $p$ aminophenol and the corresponding acid anhydride or acid chloride. The purities of the substrates were examined by HPLC.

\section{4-Propionamidophenol (3)}

Propionic anhydride $(6.46 \mathrm{ml}, 50.3 \mathrm{mmol})$ was added portionwise to $p$-aminophenol $(5.0 \mathrm{~g}, 45.8 \mathrm{mmol})$ in tetrahydrofuran (THF, $200 \mathrm{ml}$ ) at $<10^{\circ} \mathrm{C}$. After being stirred at this temperature for $1 \mathrm{~h}$, the solution was stirred for $16 \mathrm{~h}$ at ambient temperature. Activated charcoal $(500 \mathrm{mg})$ was added to the reaction mixture, which was filtered; the filtrate was concentrated to $1 / 4$ of the initial volume. Chloroform $(200 \mathrm{ml})$ was added to the solution. The resulting precipitate was filtered and washed with chloroform. The crude product was recrystallized from a $1: 1(\mathrm{v} / \mathrm{v})$ mixture of chloroform and methanol to give $6.45 \mathrm{~g}(85.3 \%)$ of the title compound as white crystals. m.p. $171.5-173^{\circ} \mathrm{C}{ }^{1} \mathrm{H}-\mathrm{NMR}$ (DMSO- $d_{6}$, $\delta \mathrm{ppm}) 1.07\left(\mathrm{t}, 3 \mathrm{H}, J=7.6 \mathrm{~Hz}, \mathrm{CH}_{3}\right) 2.26(\mathrm{q}, 2 \mathrm{H}$, $\left.J=7.6 \mathrm{~Hz}, \mathrm{CH}_{2}\right) 6.69(\mathrm{~d}, 2 \mathrm{H}, J=8.3 \mathrm{~Hz}$, aromatic $\mathrm{H}-3)$ 7.37 (d, $2 \mathrm{H}, J=8.3 \mathrm{~Hz}$, aromatic $\mathrm{H}-2) 9.13(\mathrm{~s}, 1 \mathrm{H}, \mathrm{OH})$ $9.58(\mathrm{~s}, 1 \mathrm{H}, \mathrm{NH})$

\section{4-(4-Hydroxyphenylcarbamoyl)butanoic acid (12)}

Glutaric anhydride $(11.0 \mathrm{~g}, 0.107 \mathrm{~mol})$ was added portionwise to $p$-aminophenol $(10 \mathrm{~g}, 91.6 \mathrm{mmol})$ in THF $(400 \mathrm{ml})$ at $<10^{\circ} \mathrm{C}$. After being stirred at this temperature for $1 \mathrm{~h}$, the solution was stirred for $16 \mathrm{~h}$ at ambient temperature. The white precipitate was collected and washed with THF. It was then suspended in water $(200 \mathrm{ml})$ and dissolved by the addition of a minimum amount of sodium carbonate. The solution was treated with activated charcoal $(1.0 \mathrm{~g})$, and the $\mathrm{pH}$ of the filtrate was adjusted to 3.0 with $1 \mathrm{M}$ hydrochloride solution. The resulting white precipitate was collected and washed with water, dried in vacuo to afford $13.4 \mathrm{~g}$ $(65.5 \%)$ of the title compound as a white powder. m.p. $214-215^{\circ} \mathrm{C}$ (decomp.). ${ }^{1} \mathrm{H}-\mathrm{NMR}$ (DMSO- $d_{6}, \delta \mathrm{ppm}$ ) $1.78\left(\mathrm{q}, 2 \mathrm{H}, J=7.2 \mathrm{~Hz}, \mathrm{CH}_{2}\right) 2.26\left(\mathrm{t}, 2 \mathrm{H}, J=7.2 \mathrm{~Hz}, \mathrm{CH}_{2}\right)$ $2.28\left(\mathrm{t}, 2 \mathrm{H}, J=7.2 \mathrm{~Hz}, \mathrm{CH}_{2}\right) 6.67(\mathrm{~d}, 2 \mathrm{H}, J=8.8 \mathrm{~Hz}$, aromatic $\mathrm{H}-3) 7.35(\mathrm{~d}, 2 \mathrm{H}, J=8.8 \mathrm{~Hz}$, aromatic $\mathrm{H}-2) 9.13$ (br s, 1H, OH) 9.61 (s, 1H, NH) 12.07 (br s, 1H, COOH)

\section{4-Fumaramidophenol (17)}

Dicyclohexylcarbodiimide $(20.8 \mathrm{~g}, 0.101 \mathrm{~mol})$ was added portionwise to fumaric acid monoethyl ester $(14.6 \mathrm{~g}, 0.101 \mathrm{~mol})$ in THF $(400 \mathrm{ml})$ at $<0^{\circ} \mathrm{C}$. After being stirred at this temperature for $1 \mathrm{~h}$, the reaction mixture was stirred for $4 \mathrm{~h}$ at ambient temperature. The solution was cooled down to $10^{\circ} \mathrm{C}$, at which point was added $p$-aminophenol $(5.0 \mathrm{~g}, 45.8 \mathrm{mmol})$; the mixture was then stirred for $16 \mathrm{~h}$. Activated charcoal $(500 \mathrm{mg}$ ) was added to the reaction mixture, which was filtered; the filtrate was concentrated to $1 / 4$ of the initial volume. Chloroform $(200 \mathrm{ml})$ was added to the solution and the resulting precipitate was collected and washed with chloroform. The crude product was dissolved in methanol $(200 \mathrm{ml})$, and $1 \mathrm{M}$ sodium hydroxide $(10 \mathrm{ml})$ was added to the solution, which was then stirred for $6 \mathrm{~h}$. A yellow precipitate was formed and collected, then washed with methanol and suspended in water $(200 \mathrm{ml})$. Adjusting the $\mathrm{pH}$ of the solution to 3.0 with $1 \mathrm{M} \mathrm{HCl}$ prompted precipitation. A yellow precipitate was filtered, washed with water and dried in vacuo to yield $7.10 \mathrm{~g}(74.8 \%)$ of the title compound as a yellow powder. m.p. $266-267^{\circ} \mathrm{C}$ (decomp.) ${ }^{1} \mathrm{H}-\mathrm{NMR}$ (DMSO- $d_{6}$, $\delta$ ppm) $6.66(\mathrm{~d}, 1 \mathrm{H}, J=15.5 \mathrm{~Hz}, \mathrm{CH}=\mathrm{CH}) 6.72(\mathrm{~d}, 2 \mathrm{H}$, $J=8.7 \mathrm{~Hz}$, aromatic H-2) $6.80(\mathrm{~d}, 1 \mathrm{H}, J=15.5 \mathrm{~Hz}$, $\mathrm{CH}=\mathrm{CH}) 7.49(\mathrm{~d}, 2 \mathrm{H}, J=8.7 \mathrm{~Hz}$, aromatic $\mathrm{H}-3) 10.18$ $(1 \mathrm{H}, \mathrm{s}, \mathrm{NH})$

\section{4-Methoxycarbamidophenol (9)}

Methyl chloroformate $(4.90 \mathrm{~g}, 51.9 \mathrm{mmol})$ and $10 \mathrm{~g}$ of $\mathrm{NaHCO}_{3}$ were added portionwise to $p$-aminophenol $(5 \mathrm{~g}$, $45.8 \mathrm{mmol})$ in THF $(200 \mathrm{ml})$ at $0^{\circ} \mathrm{C}$. After being stirred at this temperature for $1 \mathrm{~h}$, the solution was stirred for $16 \mathrm{~h}$ at ambient temperature. Activated charcoal $(500 \mathrm{mg})$ was added to the reaction mixture, which was filtered; the filtrate was concentrated to $1 / 4$ of the initial volume. Chloroform $(200 \mathrm{ml})$ was added to the solution, and the resulting precipitate was filtered, washed with chloroform and dried in vacuo. The crude 
product was recrystallized from a $1: 1(\mathrm{v} / \mathrm{v})$ mixture of chloroform and methanol to give $5.93 \mathrm{~g}(71.4 \%)$ of the title compound as a white powder. m.p. $114-115^{\circ} \mathrm{C}$. ${ }^{1} \mathrm{H}-\mathrm{NMR}$ (DMSO- $\left.d_{6}, \delta \mathrm{ppm}\right) 1.22(\mathrm{t}, 3 \mathrm{H}, J=7.1 \mathrm{~Hz}$, $\left.\mathrm{CH}_{3}\right) 4.07\left(\mathrm{q}, 2 \mathrm{H}, J=7.1 \mathrm{~Hz}, \mathrm{CH}_{2}\right) 6.68(\mathrm{~d}, 2 \mathrm{H}, J=8.8 \mathrm{~Hz}$, aromatic $\mathrm{H}-2) 7.21(\mathrm{~d}, 2 \mathrm{H}, J=8.8 \mathrm{~Hz}$, aromatic $\mathrm{H}-3) 9.07$ (s, 1H, OH) $9.24(\mathrm{~s}, 1 \mathrm{H}, \mathrm{NH})$

\section{Typical procedure for measuring fluorescence intensity}

A quartz cell was charged with $200 \mathrm{mM}$ aqueous hydrogen peroxide $(20 \mu \mathrm{l})$. The pre-incubated solution $\left(30^{\circ} \mathrm{C}\right)$ containing a substrate $(2.0 \mathrm{mM})$ and HRP $(100 \mu \mathrm{U} / \mathrm{ml})$ in PBS (4 ml, $\mathrm{pH} 8.0)$ was added in one portion to the cell with stirring. Immediately, fluorescence intensities were measured for over $5 \mathrm{~min}$ at $30^{\circ} \mathrm{C}$.

\section{Typical procedure of HRP assays}

4-Acetamidophenol, 4-(4-hydroxyphenylcarbamoyl)butanoic acid and HPPA were used for the HRP assays as the substrate.

A quartz cell was charged with the stock solution of hydrogen peroxide $(20 \mu \mathrm{l})$ and incubated at $30^{\circ} \mathrm{C}$. A pre-incubated solution $\left(30^{\circ} \mathrm{C}\right)$ containing HRP $(0.5$ $\mu \mathrm{U}-1 \mathrm{mU}$ ) and compound 1 (2 mM) in PBS (pH 8.0) was then added to the cell in one portion with stirring. Then, the fluorescence intensity was measured immediately over a 5 min period.

Characterization of fluorescent product derived from the enzymatic reaction of 4-acetamidophenol

A major fluorescent compound (MF) derived from the enzymatic reaction of 4-acetamidophenol with HRP was isolated, and further derived to its methyl ether (methylated MF). The structure of the methylated MF was determined based on the NMR and FAB-MS spectra, and was further confirmed by comparing the data with that of an authentic compound, 30, which was synthesized starting from 2,2'-bisphenol (Fig. 2).

To $200 \mathrm{ml}$ of a $50 \mathrm{mM}$ PBS solution (pH 8) of 4acetamidophenol (1, $1.0 \mathrm{~g}, 6.62 \mathrm{mmol}), 30 \%$ hydrogen peroxide $(1.0 \mathrm{ml})$ and $100 \mathrm{U} / \mathrm{ml}$ of HRP $(0.2 \mathrm{ml})$ were added; after this solution had been incubated at $30^{\circ} \mathrm{C}$ for $5 \mathrm{~min}$, the reaction was stopped by adding $1.0 \mathrm{ml}$ of a concentrated hydrochlolic acid solution. The reaction mixture was concentrated under reduced pressure; the residue underwent silica gel column chromatography $(5-20 \mathrm{v} / \mathrm{v} \%$ methanol in chloroform). Ninety-two milligrams of the fluorescent compound (MF) was obtained as a white powder. ${ }^{1} \mathrm{H}-\mathrm{NMR}\left(\mathrm{CD}_{3} \mathrm{OD}, \delta \mathrm{ppm}\right)$ $2.08(\mathrm{~s}, 6 \mathrm{H}), 6.86$ (dd, $2 \mathrm{H}, J=0.7 \mathrm{~Hz}, 8.2 \mathrm{~Hz}$ ), $7.34-7.38$ $(\mathrm{m}, 3 \mathrm{H}), 7.41(\mathrm{~d}, 1 \mathrm{H}, J=2.6 \mathrm{~Hz}) ;{ }^{13} \mathrm{C}-\mathrm{NMR}\left(\mathrm{CD}_{3} \mathrm{OD}\right.$, $\delta$ ppm) $23.4,117.3,122.7,125.1,127.2,132.2,152.0$, 171.4; TLC (methanol: chloroform $=1: 5$ ) $\quad R_{\mathrm{f}}=0.45$; FAB-MS (DMSO, glycerol): $m / z=301[\mathrm{M}+1]^{+}$

To a $800 \mu 1$ methanol solution of the fluorescent compound $(10 \mathrm{mg}), 200 \mu \mathrm{l}$ of $4 \mathrm{M}$ sodium hydroxide and $12 \mu$ l of iodomethane $(0.2 \mathrm{mmol})$ were added; the mixture was heated at $65^{\circ} \mathrm{C}$ for $6 \mathrm{~h}$. After removing the solvent under reduced pressure, the residue was dissolved in $100 \mu \mathrm{l}$ of methanol and purified by preparative TLC (silica gel, methanol:chloroform $=1: 10$ ). A major product was extracted from silica gel with $30 \mathrm{v} / \mathrm{v} \%$ methanol/chloroform and filtered. The concentration of the filtrate under reduced pressure gave $5.7 \mathrm{mg}(52 \%)$ of methylated compound (methylated MF) as a white powder. The ${ }^{1} \mathrm{H}-\mathrm{NMR}$ (DMSO- $d_{6}: \mathrm{CDCl}_{3}=1: 1$ ) spectra, TLC (methanol: chloroform $=1: 10$ ) and FAB-MS (DMSO, glycerol) were identical to those of authentic 5,5'-diacetamido-2,2'-dimethoxybiphenyl.

Synthesis of 5,5'-diacetamido-2,2'-dimethoxybiphenyl (Fig. 2)

2,2'-Dimethoxybiphenyl (27). To $100 \mathrm{ml}$ acetonitrile solution of 2,2'-bisphenol $(5.0 \mathrm{~g}, 26.9 \mathrm{mmol}), 4 \mathrm{M}$ sodium hydroxide $(13.5 \mathrm{ml})$ and iodomethane $(5.02 \mathrm{ml}, 80.6$ mmol) were added sequentially. The solution was heated at $65^{\circ} \mathrm{C}$ for $3 \mathrm{~h}$, and the formed precipitates were collected by filtration. Four grams $(69 \%)$ of 2,2 'dimethoxybiphenyl was obtained as light-brown needles. ${ }^{1} \mathrm{H}-\mathrm{NMR}\left(\mathrm{CDCl}_{3}, \delta \mathrm{ppm}\right) 3.79\left(\mathrm{~s}, 6 \mathrm{H}, \mathrm{CH}_{3} \mathrm{O}-\right), 6.95-$ $7.05(\mathrm{~m}, 4 \mathrm{H}$, aromatic $\mathrm{H}), 7.20-7.40(\mathrm{~m}, 4 \mathrm{H}$, aromatic $\mathrm{H})$.

2,2'-Dimethoxy-5,5'-dinitrobiphenyl (28). 2,2'-Dimethoxybiphenyl $(1.0 \mathrm{~g}, 4.67 \mathrm{mmol})$ was added to nitric acid $(d=1.42,40 \mathrm{ml})$ at $0^{\circ} \mathrm{C}$ in an ice bath; the mixture was stirred for $30 \mathrm{~min}$ without the bath. The brown suspension was poured onto ice, and the resulting lightbrown precipitate was collected by filtration, which was then washed with water and methanol to give $840 \mathrm{mg}$ (59\%) of 2,2'-dimethoxy-5,5'-dinitrobiphenyl as a slightly light brown powder. ${ }^{1} \mathrm{H}-\mathrm{NMR}$ (DMSO- $\left.d_{6}, \delta \mathrm{ppm}\right) 3.88$ $\left(\mathrm{s}, 6 \mathrm{H}, \mathrm{CH}_{3} \mathrm{O}_{-}\right), 7.34(\mathrm{~d}, 2 \mathrm{H}, J=9.2 \mathrm{~Hz}$, aromatic $\mathrm{H}-3$ and $\left.\mathrm{H}-3^{\prime}\right), 8.11$ (d, $2 \mathrm{H}, J=2.8 \mathrm{~Hz}$, aromatic $\mathrm{H}-6$ and $\mathrm{H}-6^{\prime}$ ), $8.32\left(\mathrm{dd}, J=2.8 \mathrm{~Hz}, 9.2 \mathrm{~Hz}\right.$, aromatic $\mathrm{H}-4$ and $\mathrm{H}_{-4} \mathbf{4}^{\prime}$ ).

5,5'-Diamino-2,2'-dimethoxybiphenyl (29). To a $60 \mathrm{ml}$ THF solution of 2,2'-dimethoxy-5,5'-dinitrobiphenyl (300 mg, $0.986 \mathrm{mmol}), 5 \% \mathrm{Pd} / \mathrm{C}(80 \mathrm{mg}$ ) was added; the solution was stirred under hydrogen at 1 atm for $2 \mathrm{~h}$. After removing under reduced pressure the solvent from the filtered reaction mixture, the residue was dissolved in chloroform and washed with water several times. The chloroform phase was dried with magnesium sulfate, then filtered and concentrated to afford $244 \mathrm{mg} \mathrm{(100 \% )} \mathrm{of}$ 5,5'-diamino-2,2'-dimethoxybiphenyl as a slightly reddish powder. ${ }^{1} \mathrm{H}-\mathrm{NMR}$ (DMSO- $\left.d_{6}, \delta \mathrm{ppm}\right) 3.53(\mathrm{~s}, 6 \mathrm{H}$, $\mathrm{CH}_{3} \mathrm{O}_{-}$), 4.58 (br s, $4 \mathrm{H}, \mathrm{NH}_{2}$ ), 6.33 (d, $2 \mathrm{H}, J=2.8 \mathrm{~Hz}$, aromatic H-6 and $\left.\mathrm{H}-6^{\prime}\right), 6.47(\mathrm{dd}, 2 \mathrm{H}, J=2.8 \mathrm{~Hz}, 8.6 \mathrm{~Hz}$, aromatic $\mathrm{H}-4$ and $\left.\mathrm{H}-4^{\prime}\right), 6.71(\mathrm{~d}, 2 \mathrm{H}, J=8.6 \mathrm{~Hz}$, aromatic H-3 and $\mathrm{H}_{-} \mathbf{3}^{\prime}$ ).

5,5'-Diacetamido-2,2'-dimethoxybiphenyl (30). To $10 \mathrm{ml}$ THF solution of 5,5'-diamino-2,2'-dimethoxybiphenyl (100 mg, $0.409 \mathrm{mmol})$, acetic anhydride (116 $\mu \mathrm{l}$, $1.13 \mathrm{mmol})$ and triethylamine $(112 \mu \mathrm{l}, 0.82 \mathrm{mmol})$ were added; the solution was stirred at ambient temperature for $1 \mathrm{~h}$. The resulting white precipitate was collected and washed with THF to afford $125 \mathrm{mg}(93 \%)$ of 5,5'diacetamido-2,2'-dimethoxybiphenyl as a white powder. 
Table 1 Examined substrates and fluorescence wavelengths of derived compounds

\begin{tabular}{|c|c|c|c|c|c|c|}
\hline & \multicolumn{4}{|c|}{ Acetamidophenol analog } & \multicolumn{2}{|c|}{ Fluorescence spectra } \\
\hline & $\mathbf{R}^{1}$ & $\mathbf{R}^{2}$ & $\mathrm{R}^{3}$ & $\mathrm{R}^{4}$ & $\lambda_{\mathrm{ex}} / \mathrm{nm}$ & $\lambda_{\mathrm{em}} / \mathrm{nm}$ \\
\hline 1 & $\mathbf{H}$ & $\mathrm{H}$ & $\mathbf{H}$ & $\mathrm{CH}_{3}$ & 328 & 431 \\
\hline 2 & $\mathbf{H}$ & $\mathbf{H}$ & $\mathbf{H}$ & $\mathrm{C}_{2} \mathrm{H}_{5}$ & 330 & 432 \\
\hline 3 & $\mathbf{H}$ & $\mathrm{H}$ & $\mathbf{H}$ & $\mathrm{C}_{3} \mathrm{H}_{7}$ & 328 & 431 \\
\hline 4 & $\mathrm{H}$ & $\mathrm{H}$ & $\mathbf{H}$ & $\mathrm{C}_{4} \mathrm{H}_{9}$ & 330 & 432 \\
\hline 5 & $\mathbf{H}$ & $\mathrm{H}$ & $\mathrm{CH}_{3}$ & $\mathrm{CH}_{3}$ & N.F. & N.F. \\
\hline 6 & $\mathrm{CH}_{3}$ & $\mathbf{H}$ & $\mathrm{H}$ & $\mathrm{CH}_{3}$ & 328 & 432 \\
\hline 7 & $\mathbf{H}$ & $\mathrm{CH}_{3}$ & $\mathbf{H}$ & $\mathrm{CH}_{3}$ & 322 & 419 \\
\hline 8 & $\mathrm{CH}_{3}$ & $\mathrm{CH}_{3}$ & $\mathbf{H}$ & $\mathrm{CH}_{3}$ & N.F. & N.F. \\
\hline 9 & $\mathbf{H}$ & $\mathrm{H}$ & $\mathbf{H}$ & $\mathrm{OCH}_{3}$ & 330 & 436 \\
\hline 10 & $\mathbf{H}$ & $\mathbf{H}$ & $\mathrm{H}$ & $\mathrm{OC}_{2} \mathrm{H}_{5}$ & 330 & 436 \\
\hline 11 & $\mathbf{H}$ & $\mathbf{H}$ & $\mathbf{H}$ & $\mathrm{CH}_{2} \mathrm{CH}_{2} \mathrm{COOH}$ & 326 & 432 \\
\hline 12 & $\mathbf{H}$ & $\mathbf{H}$ & $\mathbf{H}$ & $\mathrm{CH}_{2} \mathrm{CH}_{2} \mathrm{CH}_{2} \mathrm{COOH}$ & 328 & 432 \\
\hline 13 & $\mathbf{H}$ & $\mathbf{H}$ & $\mathbf{H}$ & $\mathrm{CH}_{2} \mathrm{CH}_{2} \mathrm{CH}_{2} \mathrm{CH}_{2} \mathrm{COOH}$ & 328 & 432 \\
\hline 14 & $\mathrm{H}$ & $\mathbf{H}$ & $\mathbf{H}$ & $\mathrm{CH}_{2} \mathrm{OCH}_{2} \mathrm{COOH}$ & 329 & 431 \\
\hline 15 & $\mathbf{H}$ & $\mathbf{H}$ & $\mathbf{H}$ & $\mathrm{CH}_{2} \mathrm{CH}\left(\mathrm{CH}_{3}\right) \mathrm{CH}_{2} \mathrm{COOH}$ & 328 & 431 \\
\hline 16 & $\mathbf{H}$ & $\mathrm{H}$ & $\mathbf{H}$ & $\mathrm{COOH}$ & N.F. & N.F. \\
\hline 17 & $\mathbf{H}$ & $\mathrm{H}$ & $\mathbf{H}$ & trans $-\mathrm{CH}=\mathrm{CHCOOH}$ & N.F. & N.F. \\
\hline 18 & $\mathrm{H}$ & $\mathrm{H}$ & $\mathbf{H}$ & cis $-\mathrm{CH}=\mathrm{CHCOOH}$ & N.F. & N.F. \\
\hline 19 & $\mathrm{H}$ & $\mathbf{H}$ & $\mathrm{H}$ & phenyl & N.F. & N.F. \\
\hline 20 & $\mathrm{H}$ & $\mathbf{H}$ & $\mathbf{H}$ & $\mathrm{CF}_{3}$ & N.F. & N.F. \\
\hline 21 & & $o$-acet & phenol & & N.F. & N.F. \\
\hline 22 & & $m$-ace & pheno & & N.F. & N.F. \\
\hline 23 & & 4-acet & -1-nap & & N.F. & N.F. \\
\hline 24 & & 4-acet & aniline & & N.F. & N.F. \\
\hline 25 & & 4-met & nophe & & N.F. & N.F. \\
\hline 26 & & $4-(3-h$ & pheny & onic acid (HPPA) & 322 & 411 \\
\hline
\end{tabular}

N.F., fluorescence not found.

${ }^{1} \mathrm{H}-\mathrm{NMR}$ (DMSO- $\left.d_{6}: \mathrm{CDCl}_{3}=1: 1, \delta \mathrm{ppm}\right) 3.27(\mathrm{~s}, 6 \mathrm{H}$, $\left.\mathrm{CH}_{3} \mathrm{CO}-\right), 3.65$ (s, 6H, $\left.\mathrm{CH}_{3} \mathrm{O}_{-}\right), 6.85(\mathrm{~d}, 2 \mathrm{H}, J=8.9 \mathrm{~Hz}$, aromatic $\mathrm{H}-3$ and $\left.\mathrm{H}-3^{\prime}\right), 7.25(\mathrm{~d}, 2 \mathrm{H}, J=2.6 \mathrm{~Hz}$, aromatic H-6 and H-6'), 7.48 (dd, $2 \mathrm{H}, J=2.6 \mathrm{~Hz}, 8.9 \mathrm{~Hz}$, aromatic H-4 and H-4'); TLC (methanol: chloroform $=1: 10$ ) $R_{\mathrm{f}}=0.41$; FAB-MS (DMSO, glycerol): $m / z=329$ $[\mathrm{M}+1]^{+}$.

\section{Results and Discussion}

In a fluorescent assay study using $p$-acetamidophenol analogs $(1-20)$, it was found that contamination from the parent $p$-aminophenols caused undesirable effects, such as inducing a time lag in the enzymatic reacton with HRP at low HRP activity and an instability from the stock solutions of $p$-acetamidophenols. Washing the $p$ acetamidophenol preparations with chloroform was effective in eliminating the contamination, since the solubilities of the $p$-acetamidophenol analogs are low in organic solvents, especially in chloroform, while those of the parent $p$-aminophenols are appreciable. Carboxylic acid type of $p$-acetamidophenol analogs $(11-18)$ were further purified by dissolving them in basic solutions with activated charcoals, followed by reprecipitation with dilute hydrochlolic acid. Carboxylic acid type of the analogs were highly water-soluble and low fluorescent

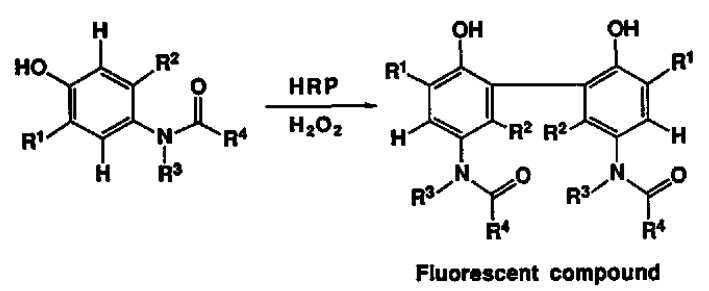

Fig. 1 Chemical structure to be the fluorescent compound in the enzymatic oxidizing reaction. $R^{1}, R^{2}, R^{3}$ and $R^{4}$ are the substituents listed in Table 1.

under the present assay conditions.

The results of the fluorescence properties of these substrates in the enzymatic oxidation with HRP and hydrogen peroxide are summerized in Table 1 . The general structure of the major fluorescent compounds which we propose in the HRP-mediated oxidation is shown in Fig. 1.

Alkylation of the amide moiety $\left(\mathrm{R}^{3}\right)$, the presence of an $o$ - or $m$-hydroxy group to the acetamide group, introducing a double bond or an aromatic group next to the amide group $\left(R^{4}\right)$, or substituting the hydrogen on a benzene ring with methyl groups cause a reduction in their fluorescence intensity. Based on these observa- 


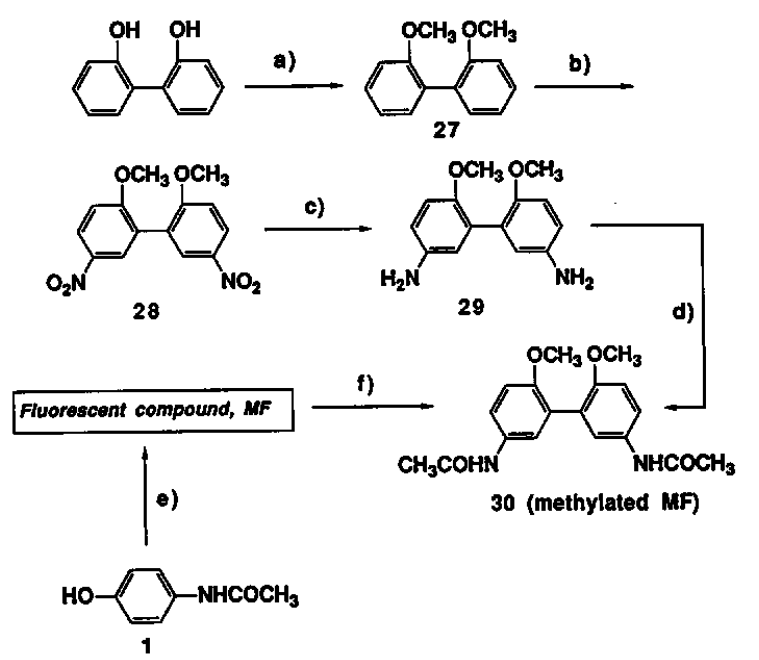

Reagents and conditions: a) $\mathrm{CH}_{3} \mathrm{l}, \mathrm{CH}_{3} \mathrm{CN}, 65 \mathrm{C}$; b) $\mathrm{HNO}_{3}$ (d-1.42), 0-20 C c) $\mathrm{H}_{2}, 5 \% \mathrm{Pd} / \mathrm{C}$, THF, ambient temperature; d) Ac, O, TEA, THF, ambient temperature; e) $\mathrm{HRP}, \mathrm{H}_{2} \mathrm{O}_{2}, \mathrm{PBS}, 30^{\circ} \mathrm{C}$; 1 ) $\mathrm{CH}_{3} \mathrm{l}, \mathrm{NaOH}, \mathrm{MeOH}, 65^{\circ} \mathrm{C}$.

Fig. 2 Synthetic scheme of 5,5'-diacetamido-2,2'-dimethoxybiphenyl.

tions, the hydroxy group on the $p$-position, the hydrogen atom on the amide group and no substituent on the benzene ring of $p$-acetamidophenol seem to be structural requirements to give fluorescent products in enzymatic oxidation. However, the structure of the fluorescent spieces has not yet been elucidated.

The fluorescence intensities of $p-(N$-alkylcarbonyl)aminophenols, including $p$-( $N$-carboxyalkylcarbonyl)aminophenols $(11-15)$, in the enzymatic reaction were twenty-times greater than that of HPPA in the HRP activity range $0.5-100 \mu \mathrm{U} / \mathrm{ml}$. Though alkyloxy groups were also good as an $\mathrm{R}^{4}$ substituent to achieve a high fluorescence intensity in the enzymatic oxidation reaction, the stabilities of stock solutions of compounds 9 and 10 were inferior to those of the $p$-alkylamidophenols.

The oxidation reaction mixture from $p$-acetamidophenol (1), HRP and hydrogen peroxide was analyzed by HPLC (Fig. 3), and a major fluorescent product (MF) was isolated. The ${ }^{1} \mathrm{H}$ and ${ }^{13} \mathrm{C}-\mathrm{NMR}$ spectra (Fig. 4a and $4 \mathrm{~b}$, respectively) and FAB-MS data were compatible with 5,5'-diacetamido-2,2'-bisphenol. We confirmed this structure by a synthetic approach. 5,5'Diacetamido-2,2'-dimethoxybiphenyl (30) was synthesized from 2,2'-bisphenol as a starting material, as shown in Fig. 2. ${ }^{1} \mathrm{H}-\mathrm{NMR}$, FAB-MS spectra, TLC and the HPLC behavior of 5,5'-diacetamido-2,2'-dimethoxybiphenyl were identical to that of the methylated fluorescent compound (methylated MF).

The FAB-MS study of the crude oxidation product from $p$-acetamidophenol (1) suggested that other fluorescent products were probably the trimer and tetramer linked at the $o$-position of $p$-acetamidophenols, such as 5,5'-diacetamido-2,2'-bisphenol (data not shown).

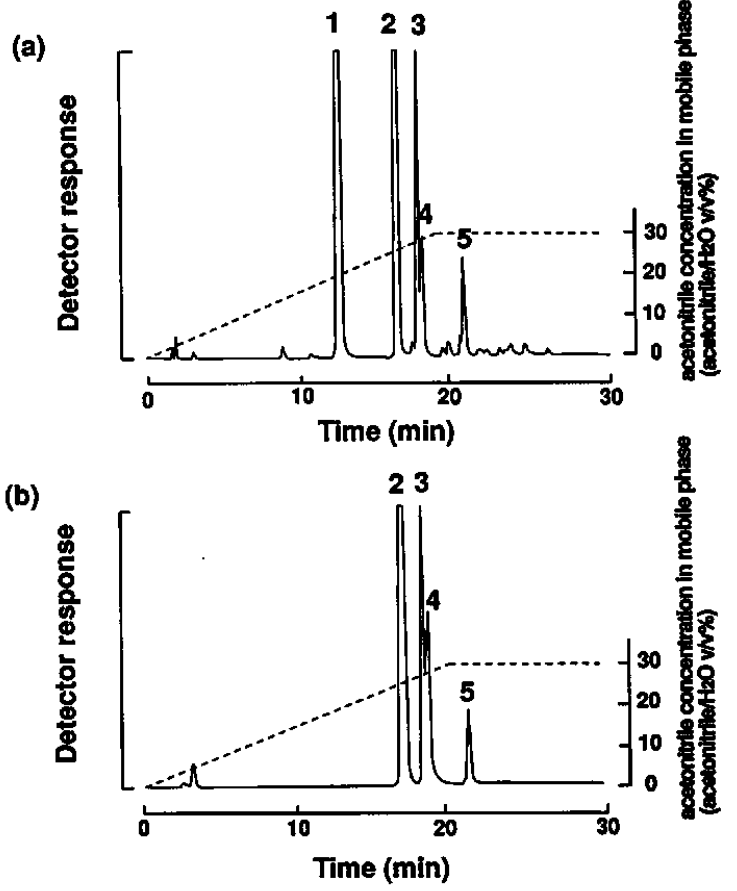

Fig. 3 HPLC chromatogram of the HRP enzymatic reaction solution derived from 4-acetamidophenol with UV detection (a) or fluorescence detection (b). Column, TSKgel ODS120T (150 mm $\times 4.6 \mathrm{~mm}$ i.d.; particle size, $5 \mu \mathrm{m}$ ); mobile phase, $0-30 \%$ acetonitrile $/ \mathrm{H}_{2} \mathrm{O}$ (linear gradient for $20 \mathrm{~min}$, then $30 \%$ acetonitrile $/ \mathrm{H}_{2} \mathrm{O}$ over next $20 \mathrm{~min}$ ); flow rate, $0.75 \mathrm{ml} / \mathrm{min}$; detection, UV $254 \mathrm{~nm}$; fluorescence, $\lambda_{\mathrm{ex}}=328 \mathrm{~nm}$ and $\lambda_{\mathrm{em}}=430 \mathrm{~nm}$; column temperature, $40^{\circ} \mathrm{C}$; $2 \mu \mathrm{l}$ of the reaction solution was injected. 1: 4-acetamidophenol; 2: 5,5'-diacetamido-2,2'-bisphenol; 3, 4, 5 were unknown fluorescent compounds.
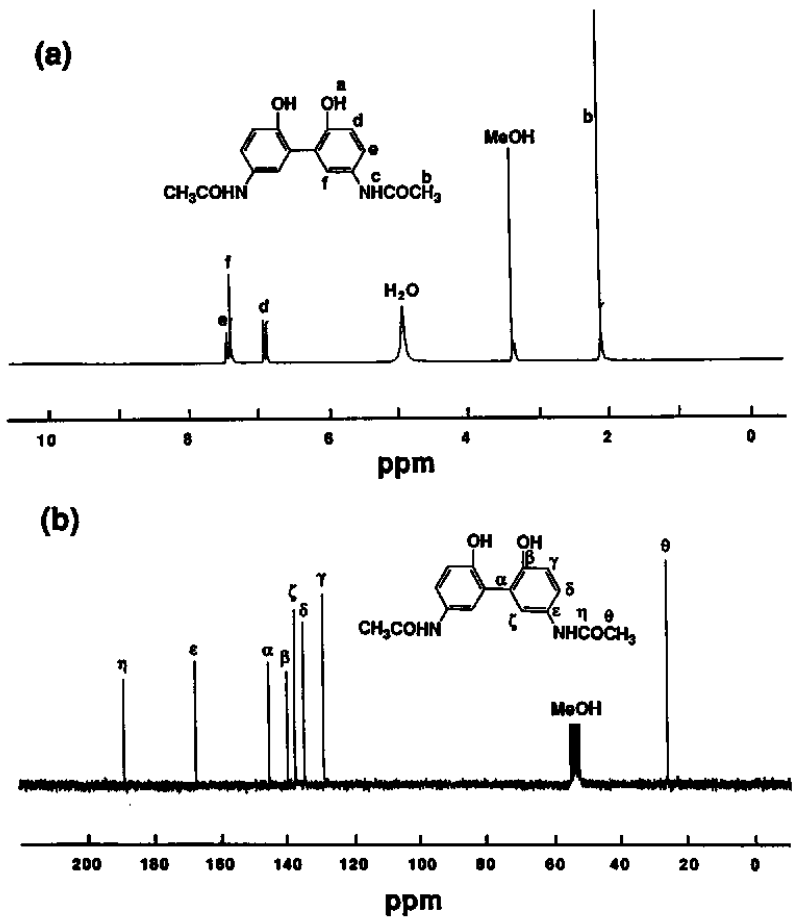

Fig. $4{ }^{1} \mathrm{H}$ - (a) and ${ }^{13} \mathrm{C}-\mathrm{NMR}$ (b) spectrum of the isolated fluorescent product derived from 4-acetamidophenol. 


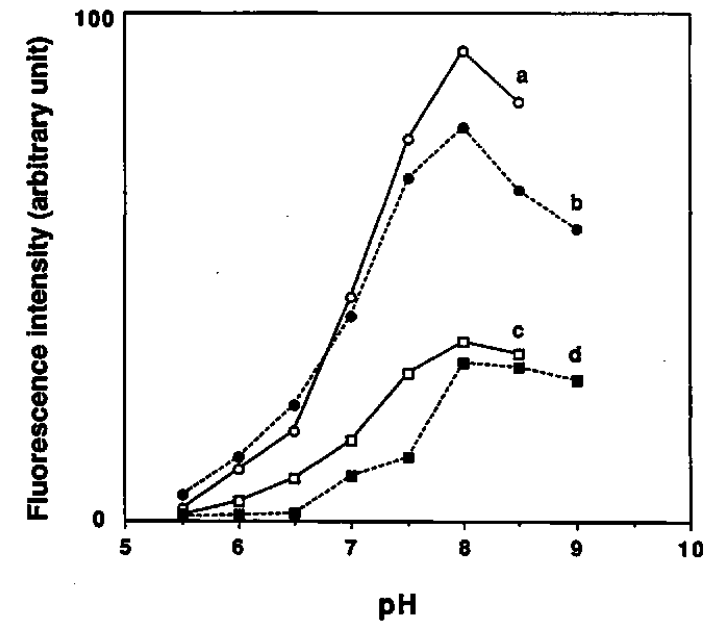

Fig. $5 \mathrm{pH}$ dependency of the enzymatic oxidizing reaction of acetamidophenols on the fluorescence intensity. a, 4-acetamidophenol in $50 \mathrm{mM}$ PBS buffer; b, 4-acetamidophenol in 50 mM Good's buffers; c, 4-(4-hydroxyphenylcarbamoyl)butanoic acid in $50 \mathrm{mM}$ PBS buffer; d, 4-(4-hydroxyphenylcarbamoyl)butanoic acid in $50 \mathrm{mM}$ Good's buffers. The following buffers were used: $50 \mathrm{mM}$ PBS (pH 5.5-8.5), $50 \mathrm{mM}$ MES (pH 5.5), $50 \mathrm{mM}$ HEPES (pH 6-8.5), $50 \mathrm{mM}$ Tris- $\mathrm{HCl}$ (pH 9).

HPPA also gives several fluorescent compounds in the enzymatic oxidation reaction which have oligomeric similar structures.

The effect of $\mathrm{pH}$ on the fluorescence intensities in the $\mathrm{HRP}-\mathrm{H}_{2} \mathrm{O}_{2}$ oxidation of 1 and 12 is shown in Fig. 5. It was shown that the reaction at $\mathrm{pH} 8$ gave the maximum fluorescent intensity in both PBS and Good's buffers. In general, PBS buffers tend to give a slightly higher fluorescence intensity than do Good's buffers. The concentration dependencies of $p$-acetamidophenol and hydrogen peroxide on the fluorescence intensity were examined (Figs. 6 and 7, respectively), which indicated that the optimal concentration of 1 was $2 \mathrm{mM}$ and that of 12 was between 3 and $6 \mathrm{mM}$ in the final assay solutions; $1 \mathrm{mM}$ of hydrogen peroxide was required for a sensitive HRP assay. In HPPA assay, optimal concentration of hydrogen peroxide under similar conditions was $0.5 \mathrm{mM}$. In Fig. 6, there is a concentration of $p$-acetamidophenol which gives the maximum fluorescence intensity. Although the reason is not clear, an inhibition of HRP activity by $p$-acetamidophenol or products is a possibility. The fluorescence intensity of the enzymatic oxidation reaction of compound $\mathbf{1 2}$ was stable for over several hours after stopping the reaction by addition of $1 \mathrm{M}$ hydrochloric acid.

The detection limit of HRP using $p$-acetamidophenol under optimized conditions is approximately $0.5 \mu \mathrm{U}$ at a signal-to-noise ratio of 3 . This is more than twentytimes higher than that of HPPA, as shown by the standard curve, which plots the fluorescence intensity against the HRP activity (Fig. 8). The figure shows that

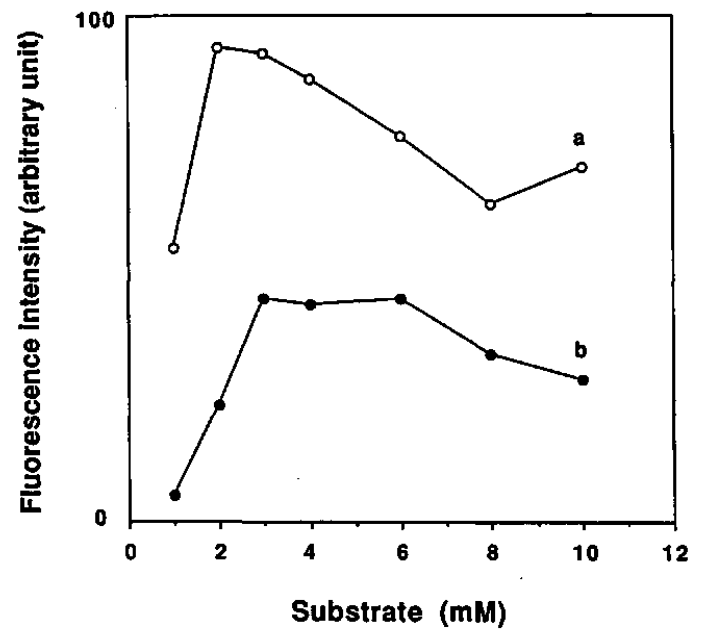

Fig. 6 Fluorescence intensities of 4-acetamidophenols as a function of the concentration. a, 4-acetamidophenol; b, 4-(4-hydroxyphenylcarbamoyl)butanoic acid $50 \mathrm{mM}$ PBS buffer (pH 8.0); HRP, $1 \mathrm{mU} / \mathrm{ml} ; \mathrm{H}_{2} \mathrm{O}_{2}, 0.8 \mathrm{mM}$, and several concentration of acetamidophenols mixed solution was incubated for $3 \mathrm{~min}$ at $30^{\circ} \mathrm{C}$. The fluorescence intensities were measured at $430 \mathrm{~nm}\left(\lambda_{\mathrm{ex}}=328 \mathrm{~nm}\right)$.

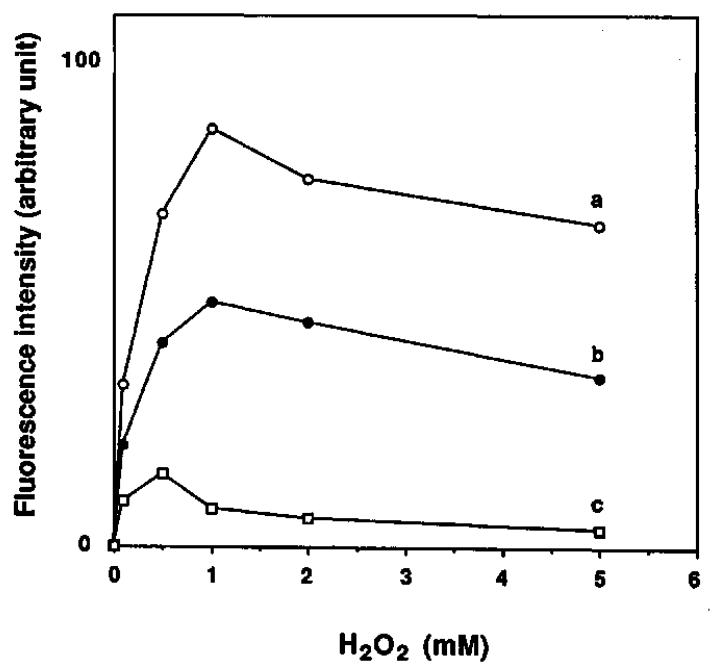

Fig. 7 Fluorescence intensities versus the concentrations of hydrogen peroxide. a, 4-acetamidophenol; b, 4-(4-hydroxyphenylcarbamoyl)butanoic acid; c, HPPA $50 \mathrm{mM}$ PBS buffer (pH 8.0), HRP $1 \mathrm{mU} / \mathrm{ml}, \mathrm{H}_{2} \mathrm{O}_{2} 0.8 \mathrm{mM}$, substrate (4acetamidophenol $3 \mathrm{mM}$, 4-(4-hydroxyphenylcarbamoyl)butanoic acid $4 \mathrm{mM}$, HPPA $8 \mathrm{mM}$ ) and several concentration of hydrogen peroxide mixed solution was incubated for $3 \mathrm{~min}$ at $30^{\circ} \mathrm{C}$. Fluorescence intensities were measured at $430 \mathrm{~nm}$ $\left(\lambda_{\text {ex }}=328 \mathrm{~nm}\right)$.

the linear dynamic range of HRP activity is between 0.5 and $100 \mu \mathrm{U}$. The reproducibility of the fluorescence intensity measurement was within $5 \%$ in 5 experiments using compound 12, as indicated in Fig. 8. When the HRP activity was higher than $1 \mathrm{mU} / \mathrm{ml}$, the generated 


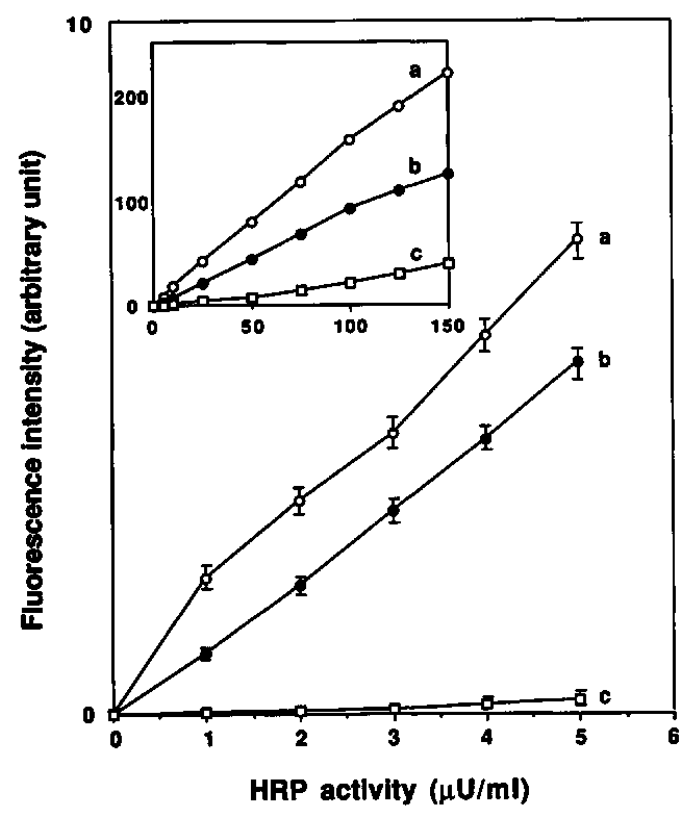

Fig. 8 Fluorescence intensities versus HRP activities. a, 4acetamidophenol; b, 4-(4-hydroxyphenylcarbamoyl)butanoic acid; c, HPPA $50 \mathrm{mM}$ PBS buffer (pH 8.0), substrate (4acetamidophenol $3 \mathrm{mM}$, 4-(4-hydroxyphenylcarbamoyl)butanoic acid $4 \mathrm{mM}$ ), $\mathrm{H}_{2} \mathrm{O}_{2}$ (4-acetamidophenols $1 \mathrm{mM}$, HPPA $0.5 \mathrm{mM}$ ), and several activities of HRP mixed solution was incubated for $3 \mathrm{~min}$ at $30^{\circ} \mathrm{C}$. Fluorescence intensities were measured at $430 \mathrm{~nm}\left(\lambda_{\mathrm{ex}}=328 \mathrm{~nm}\right)$. fluorescence decreased in a time-dependent manner (data not shown). That the fluorescent 5,5'-diacetamido-2,2'bisphenol might be further oxidized to non-fluorescent compounds is a possible cause.

These observations indicate that $p$-acetamidophenol compound 12 is the most easy-to-use and sensitive substrate among phenol analogs for the measurement of low HRP activity.

\section{References}

1. K. Tamaoku, Y. Murao, K. Akiura and Y. Ohkura, Anal. Chim. Acta, 136, 121 (1982).

2. K. Tamaoku, K. Ueno, K. Akiura and Y. Ohkura, Chem. Pharm. Bull., 30, 2492 (1982).

3. M. Shiga, M. Saito and K. Kina, Anal. Chim. Acta, 153, 191 (1983).

4. G. G. Guilbault, P. J. Brignac and M. Zimmer, Anal. Chem., 40, 190 (1968).

5. G. G. Guilbault, P. J. Brignac and M. Juneau, Anal. Chem., 40, 1256 (1968).

6. K. Zaitsu and Y. Ohkura, Anal. Biochem., 109, 109 (1980).

7. S. Hashida, K. Nakagawa, S. Yoshitake, M. Imagawa, E. Ishikawa, Y. Endo, S. Ohtaki, Y. Ichioka and K. Nakajima, Anal. Lett., 16(B1), 31 (1983).

8. K. Nakamura, S. Satomura and S. Matsuura, Anal. Chem., 65, 613 (1993).

9. J. Putter, "Methods of Enzymatic Analysis", ed. H. U. Bergmeyer, Vol. 2, pp. 685 - 690, Academic Press, New York, 1974. 